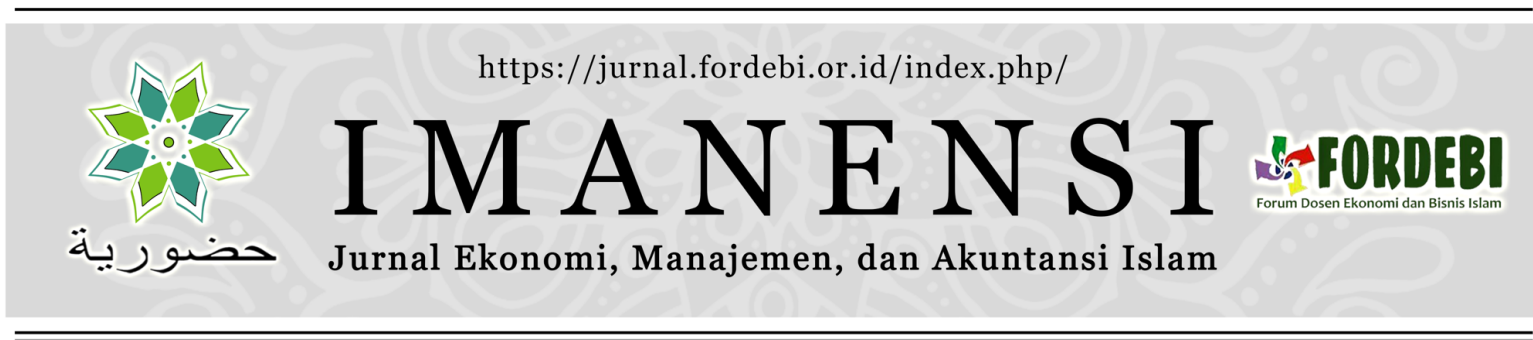

\title{
INDIKATOR KINERJA DAN MANAJEMEN BIDANG LINGKUNGAN DALAM KONSEP MAQASHID SYARIAH
}

\author{
Saiful Muchlisa,1* \\ a Universitas Islam Negeri Alauddin Makassar. Jalan H.M. Yasin Limpo No.36. Romangpolong-Gowa, \\ 92118, Indonesia \\ 1saiful.cahayaislam@gmail.com*
}

*Corresponding author

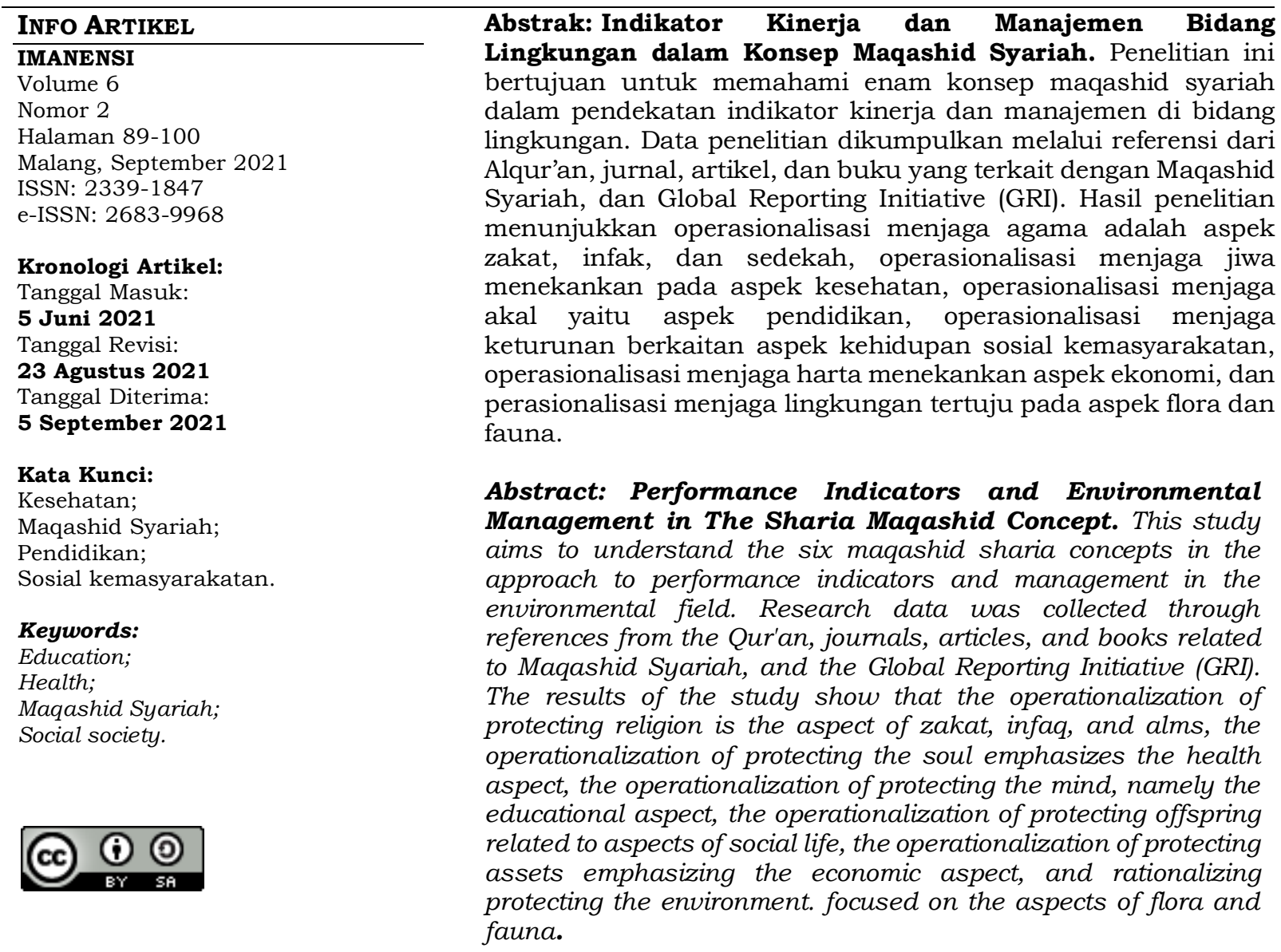

Disitasi sebagai: Muchlis, S. (2021). Indikator Kinerja dan Manajemen Bidang Lingkungan dalam Konsep Maqashid Syariah. IMANENSI: Jurnal Ekonomi, Manajemen, dan Akuntansi Islam, 6(2), 89-100. https://doi.org/10.34202/imanensi.6.2.2021.89-100.

\section{PENDAHULUAN}

Negara-negara di seluruh dunia menjadikan persoalan lingkungan merupakan isu sentral yang paling utama, tidak terkecuali di Indonesia. Berdirinya sebuah entitas bisnis, selain memberikan dampak positif, terdapat pula dampak negatifnya yang tidak disadari oleh para pelaku bisnis, seperti eksploitasi sumber daya dan rusaknya ekosistem lingkungan (Zulfikar et al., 2020). Kehancuran 
ekosistem planet yang dikuras dan dikeruk secara serakah dan membabi buta, menyebabkan terjadinya krisis ekologi global maupun nasional yang semakin parah dan menghawatirkan (Lako, 2018;1). Isu-isu lingkungan hidup selalu mengemuka, dan menjadi sebuah fenomena yang hangat diperbincangkan di seluruh dunia. Lingkungan hidup adalah maksud dan tujuan syariah (maqashid syariah) yang harus senantiasa dijaga, dan dipertahankan eksistensinya. Lingkungan alam yang diciptakan Allah Subhanahu WaTa'ala, tidaklah hanya sebatas untuk kepentingan manusia saja, melainkan juga untuk kepentingan seluruh makhluk hidup lainnya di permukaan bumi ini (flora dan fauna) (Muchlis, 2018).

Enam konsep maqashid asy-syari'ah bertujuan untuk menciptakan kemaslahatan umat manusia dalam bentuk keadilan sosial. Nilai-nilai Islam dan tujuan syari'ah merupakan dasar atau acuan dalam menjalankan organisasi Islam (Mulawarman dan Triyuwono, 2007). Perlindungan terhadap mashlahah, yaitu meliputi; kehidupan (an-nafs), ilmu (al-'ilm), keimanan (ad-dien), kelangsungan keturunan (an-nash), dan harta (al-maal). Demi kelangsungan hidup yang lebih baik dan terhormat, kelima konsep tersebut merupakan sarana yang sangat dibutuhkan (Bahsoan, 2011). Maqashid al-Syariah dan juga urgensi pemeliharaan lingkungan, didapatkan hasil bahwa, menjaga dan memelihara lingkungan, sama pentingnya dengan menjaga dan memelihara agama. Pemeliharaan lingkungan (konservasi lingkunga) jika dilihat dari pandangan ushul fiqh, harus berlandasan maqashid syariah dimana tujuannya adalah untuk mencapai maslahah, baik di dunia maupun akhirat. Meniadakan tujuan syariah adalah perbuatan dosa, dan termasuk tindakan yang merusak lingkungan (Khoerunisa, 2020). Allah Subhana WaTa'ala berfirman dalam Al-Qur'an surat Ar-Rum ayat 41, yaitu:

Terjemahnya:

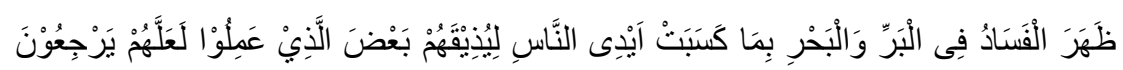

Telah nampak kerusakan di darat dan di laut disebabkan Karena perbuatan tangan manusi, supaya Allah merasakan kepada mereka sebahagian dari (akibat) perbuatan mereka, agar mereka kembali (ke jalan yang benar).

Entitas bisnis yang hanya memperhatikan diri sendiri dalam mengejar materi, tidak peduli atas dampak buruk yang akan ditimbulkan pada lingkungan sekitarnya merupakan melakukan tindakan yang sewenang-wenang karena dapat merusak lingkungan (Anis et al., 2020). Wujud pemenuhan kewajiban perusahaan kepada masyarakat, yaitu dengan mematuhi peraturan pemerintah dalam mengelola dampak lingkungan (Afazis dan Handayani. 2020). Tanah Borneo adalah tanah yang terbesar dan terluas di Indonesia, yaitu sekitar 40.800.000 hektar luas hutannya. Keserakahan hidup manusia yang menjadikan hutan sebagai sasaran untuk pemenuhan kebutuhan hidupnya, mengakibatkan hijau daun hutan Indonesia dari waktu ke waktu sudah tampak gersang dan tandus. Rizal (2021) menyebutkan, adanya perkebunan monokultur dan lubang tambang batubara, mengakibatkan dalam lima puluh tahun terakhir, tanah Borneo kehilangan sebagian dari hutan hujan penyerap air. Bencana Krisis Iklim di tanah Borneo disebabkan volume pemanasan global yang meningkat, akibat terbakarnya lahan batubara dan punahnya hutan lindung.

Yusuf Qaradhawi menyatakan menjaga planet sama halnya menjaga agama. Mencoreng kesucian agama dan meniadakan ketentuan-ketentuan syari'ah, serta mengabaikan konservasi lingkungan, dapat menyebabkan terjadinya kerusakan lingkungan (Abdullah, 2010). Mengutip pernyataan Profesor Quraisy Shihab yang menyebutkan bahwa, saat ini maksud dan tujuan syariah, tidak lagi hanya dibatasi pada lima konsep, namun konsep maqashid syariah juga termasuk di dalamnya menjaga dan memelihara lingkungan. Dewasa ini, terdapat tujuh konsep maqashid 
syariah yaitu menjaga dan memelihara umat. Konsep menjaga dan memelihara umat tidak dibahas, karena esensi dari konsep menjaga dan memelihara agama, didalamnya sudah mencakup nilai-nilai konsep maqashid syariah dalam hal menjaga dan memelihara umat.

Energi dan air adalah input, emisi, efluen, dan limbah, termasuk juga keanekaragaman hayati, transportasi, dan dampak yang berkaitan dengan produk dan jasa, serta kepatuhan dan biaya lingkungan adalah output. Semua komponen tersebut adalah lingkungan yang sesungguhnya (Global Reporting Initiative; 2013). Khoerunnisa (2020) konservasi lingkungan hidup (flora fauna) adalah ad-dharuriyat, yaitu suatu perkara yang menimbulkan kestabilan kehidupan umat manusia. Jika ini tidak terwujud, maka akan menimbulkan kekacauan dan ketidakstabilan dalam kehidupan masyarakat. Manusia akan mengalami kesengsaraan hidup di dunia, maupun di akhirat. maqashid dharuriyat mencakup perlindungan terhadap agama, jiwa, akal, keturunan, harta, dan lingkungan. inilah yang menjadi dasar dan tujuan penting dilakukan penelitian mengenai indikator kinerja dan manajemen bidang lingkungan dalam konsep maqashid syariah

\section{METODE}

Penelitian ini dilakukan dengan mengumpulkan berbagai referensi yang terkait langsung dengan enam konsep Maqashid Syariah dan referensi tentang pendekatan indikator kinerja dan manajemen di bidang lingkungan, sebagaimana yang tertuang dalam Global Reporting Initiative (GRI). Analisis dilakukan dengan menghubungkan pendekatan indikator kinerja dan manajemen di bidang lingkungan-(GRI), dengan enam konsep maqashid syariah dalam hal menjaga dan memelihara jiwa, menjaga dan memelihara akal, menjaga dan memelihara agama, menjaga dan memelihara harta, menjaga dan memelihara keturunan, serta menjaga dan memelihara lingkungan.

Enam konsep maqashid syariah merupakan maksud dan tujuan syariah yang komprehenship, dan wajib diterapkan oleh semua entitas dalam hal menjaga dan memelihara lingkungan hidup, secara falah dan holistik. Operasionalisasi enam konsep maqashid Syariah yaitu: menjaga dan memelihara agama, jiwa, akal keturunan, harta, dan lingkungan.

\section{HASIL DAN PEMBAHASAN}

\subsection{Menjaga dan Memelihara Agama dalam Pendekatan Indikator Kinerja dan Manajemen di Bidang Lingkungan}

Pendekatan indikator kinerja, dan manajemen di bidang lingkungan adalah esensi nilai-nilai maqashid syariah dalam menjaga dan memelihara agama. Dalam hal ini, keharusan dan kewajiban bagi setiap umat Islam untuk menjalankan dan menegakkan syariat Islam secara kaffah. Syariat Islam bisa ditegakkan dengan menunaikan semua perintah Allah Subhana Wata'ala yang tertuang dalam sumbersumber hukum Islam. Esensi keimanan dan ketaqwaan kepada Allah Subhana Wata'ala adalah terciptanya tata nilai kehidupan yang harmonis, rukun, penuh kedamaian dan kesejahteraan di tengah-tengah lingkungan masyarakat. Artinya, jika penduduk di suatu negeri menjadikan ajaran agama sebagai pedoman dan falsafah hidupnya, maka niscaya akan tercipta lingkungan alam yang memberikan kebaikan dan manfaat bagi seluruh kehidupan umat manusia. Allah Subhana Wata'ala berfirman dalam al-Qur'an surat al-A'raf ayat 96.

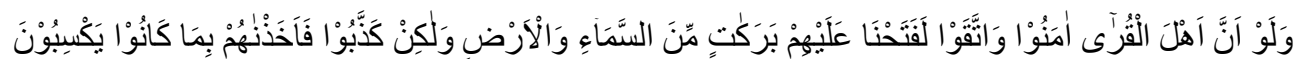


Terjemahnya:

Jikalau sekiranya penduduk negeri-negeri beriman dan bertakwa, pastilah kami akan melimpahkan kepada mereka berkah dari langit dan bumi, tetapi mereka mendustakan (ayatayat kami) itu, Maka kami siksa mereka disebabkan perbuatannya.

Mengutip pernyataan Shihab dalam kajian Ushul Figh, yaitu banyak para ulama yang memahami dan menunjukkan bahwa, pada dasarnya segala apa yang terbentang di bumi ini dapat digunakan oleh manusia, kecuali jika ada dalil lain yang melarangnya. Sebagian kecil ulama tidak memahami demikian. Mereka mengharuskan adanya dalil yang jelas untuk memahami boleh atau tidaknya sesuatu, bahkan ada juga yang berpendapat, bahwa pada dasarnya segala sesuatu yang terlarang kecuali kalau ada dalil yang menunjukkan izin menggunakannya (Gassing. 2005; 131). Menurut Salim (1986;170), dalam hubungannya dengan pengelolaan lingkungan hidup, kebanyakan sumber daya alam yang relevan bagi (krisis) lingkungan, seperti udara, air, hutan, laut, sungai, danau, dan lain-lain sumber daya alam yang penting untuk kelestarian lingkungan hidup, pada umumnya tidak boleh dimiliki oleh manusia secara perorangan. Dampaknya timbul kecenderungan untuk menggunakannya secara boros dan tidak bertanggungjawab. Mengambil seenaknya secara gratis dari alam tanpa mau membayar.

\subsection{Menjaga dan Memelihara Jiwa dalam Pendekatan Indikator Kinerja dan Manajemen di Bidang Lingkungan}

Esensi pendekatan indikator kinerja, dan manajemen di bidang lingkungan pada konsep maqashid syariah dalam menjaga dan memelihara jiwa yaitu, setiap individu tidak boleh bunuh diri atau menghilangkan nyawa sendiri, dan membunuh atau menghilangkan nyawa orang lain tanpa sebab yang dibenarkan oleh syariat. Manusia sebagai khalifah dan mahluk sosial, diharapkan dapat mengayomi kehidupan seluruh makhluk hidup di lingkungan alam ini. Manusia tidak boleh membunuh dan memusnakan ekosistem dari habitat makhluk hidup di udara, di darat, dan di air (laut, danau, dan sungai). Jika manusia membunuh dan membinasakan mahluk lain, tanpa alasan yang di benarkan oleh syar'i, sesungguhnya ia telah membuat kerusakan lingkungan alam yang pada akhirnya akan menimbulkan biaya tinggi (higt cost) dalam menaggulangi dampak dari kerusakan lingkungan tersebut. Allah Subhana Wata'ala berfirman dalam al-Qur'an surat Al-A'raf ayat 56, yaitu:

Terjemahnya:

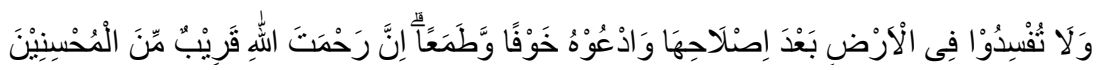

Dan janganlah kamu membuat kerusakan di muka bumi, sesudah (Allah) memperbaikinya dan berdoalah kepada-Nya dengan rasa takut (Tidak akan diterima) dan harapan (akan dikabulkan). Sesungguhnya rahmat Allah amat dekat kepada orang-orang yang berbuat baik.

Substansi Firman Allah di atas, yaitu semua malapetaka yang meluluh lantahkan planet dunia ini, dan berujung pada penderitaan kerugian dalam segala aspek kehidupan, itu semua terjadi diakibatkan karena ulah perbuatan dari manusia itu sendiri. Hukum sebab-akibat atau kausalitas berlaku pada semua fenomena dan peristiwa yang terjadi di permukaan planet dunia ini. Akibat manusia memusnahkan planetnya sendiri, maka mereka pula yang akan merasakan kesengsaraan, dan kepedihan hidup yang berkepanjangan (Gassing. 2005; 24-25).

Pendekatan indikator kinerja dan manajemen di bidang lingkungan, pada tataran operasionalisasi konsep maqashid syariah dalam menjaga dan memelihara jiwa, yaitu menekankan pada aspek kesehatan lingkungan. Dalam hal ini PT BMI cabang Surakarta berkontribusi nyata memberikan bantuan dana untuk mendirikan poliklinik di samping Kampus Universitas Sebelas Maret (UNS) Surakarta. 


\subsection{Menjaga dan Memelihara Akal dalam Pendekatan Indikator Kinerja dan Manajemen di Bidang Lingkungan}

Esensi pendekatan indikator kinerja, dan manajemen di bidang lingkungan pada konsep maqashid syariah dalam menjaga dan memelihara akal, yaitu dengan menyelenggarakan pendidikan gratis, melalui penyaluran santunan beasiswa bagi para murid dan mahasiswa yang berakhlatul-karimah, serta murid dan mahasiswa dari kalangan yang tidak mampu (miskin). Hakekat sebuah dunia pendidikan adalah, untuk menghasilkan manusia-manusia yang unggul, cerdas, berintegritas, jujur, amanah, dalam bingkai keimanan dan ketaqwaan kepada Sang Khaliq. Allah Subhana Wata'ala berfirman dalam al-Qur'an surat Al-Mujadalah ayat 11, yaitu:

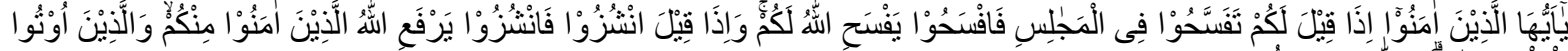

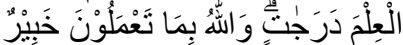

Terjemahnya:

Hai orang-orang beriman apabila kamu dikatakan kepadamu: "Berlapang-lapanglah dalam majlis", Maka lapangkanlah niscaya Allah akan memberi kelapangan untukmu. dan apabila dikatakan: "Berdirilah kamu", Maka berdirilah, niscaya Allah akan meninggikan orang-orang yang beriman di antaramu dan orang-orang yang diberi ilmu pengetahuan beberapa derajat, dan Allah Maha mengetahui apa yang kamu kerjakan.

Akal yang sehat senantiasa melahirkan pemikiran-pemikiran dan ide-ide cemerlang yang akan memberikan kebaikan dan kemaslahatan hidup manusia di dunia dan di akhirat kelak. Namun sebaliknya, jika seseorang akalnya rusak atau kotor, maka segala bentuk tindak tanduknya akan mengakibatkan kerusakan pada lingkungan kehidupan masyarakat, dan bahkan tidak menutup kemungkinan akan membawa kerusakan yang lebih besar pada lingkungan alam dan sekitarnya. Pendekatan indikator kinerja dan manajemen di bidang lingkungan, pada tataran operasionalisasi maksud dan tujuan syariah dalam menjaga dan memelihara akal, yaitu mengambil sampel di PT Bank Muamalat Indonesia cabang Surakarta. PT BMI cabang Surakarta menyalurkan santunan biaya pendidikan bagi anak-anak yang kurang mampu, dan yang berdomisili disekitar lingkungan PT BMI cabang Surakarta, disertai dengan surat keterangan dari RT dan Kelurahan setempat. Disamping itu, PT BMI cabang Surakarta juga memberikan bantuan biaya pendidikan bagi anak-anak kru (karyawan), dalam lingkungan PT BMI cabang Surakarta (Muchlis, 2018).

\subsection{Menjaga dan Memelihara Keturunan dalam Pendekatan Indikator Kinerja dan Manajemen di Bidang Lingkungan}

Gassing (2010) menyatakan bahwa, Islam melarang berzina dan dianjurkan untuk menikah (walimatul uru'sy). Terjadinya transaksi miras dan ektesi, serta maraknya perilaku yang dekat dengan zina dan kemaksiatan, dikhawatirkan akan mengancam dalam menjaga dan memelihara keturunan. Dalam Islam, segala upaya yang dilakukan untuk mencegah kemaksiatan, dikenal dengan prinsip sadd alzari'ah. Allah Subhana WaTa'ala berfirman dalam al-Qur'an surat al-Isra' ayat 32.

Terjemahnya:

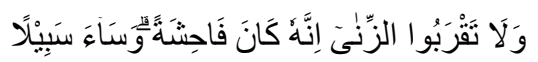

Dan janganlah kamu mendekati zina; Sesungguhnya zina itu adalah suatu perbuatan yang keji. dan suatu jalan yang buruk.

Allah Subhana WaTa'ala melarang laki-laki dan perempuan berhalwat, karena yang ketiganya adalah syetan. Berhalwat terindikasi kuat untuk mengarah ke perzinahan. Laki-laki perjaka dan perempuan gadis yang berzina, maka dihukum dera 100 kali cambukan, kemudian diasingkan, dikucilkan, bahkan dibuang dari kehidupan masyarakat. Hukuman pelaku zina bagi yang telah menikah, baik laki- 
laki maupun perempuan, yaitu hukuman rajam. Separuh badannya ditanam, kemudian setiap orang yang melintas wajib melempar dengan batu sampai mati. Tujuannya adalah memberikan efek jera bagi yang lain, dan dihadapan Allah dosa pelaku zina bisa diampuni (Muin. 2014). Dalam tataran holistik dan falah, perzinahan dan lingkungan memiliki hubungan yang erat, yaitu kerusakan lingkungan bukan hanya pada aspek pencemaran udara, limbah pabrik, dan penebangan hutan secara liar, namun akibat yang ditimbulkan dari zina yaitu hamil diluar pernikahan. Hal ini tentunya akan merusak nazab dan masalah ahli waris nantinya. Disamping itu, perzinahan akan berdampak pada lepas tanggungjawab dari pihak laki-laki, dan tentunya hal ini akan menjadi aib bagi pihak perempuan, dan hal ini tentunya akan merusak lingkungan kehidupan bermasyarakat dan sebuah rumah tangga.

Muchlis (2018) menyebutkan esensi nilai-nilai maqashid syariah pada konsep menjaga dan memelihara keturunan, dalam pendekatan indikator kinerja dan manajemen di bidang lingkungan, adalah terpenuhinya unsur rohani dan jasmani. Unsur rohani, yaitu peningkatan pemahaman keagamaan (keislaman) bagi para generasi muda, dan di lingkungan masyarakat pada umumnya. Sedangkan unsur jasmani, yaitu peningkatan kesejahteraan masyarakat melalui pelayanan kesehatan yang memadai, dan keselamatan kerja karyawan.

\subsection{Menjaga dan Memelihara Harta dalam Pendekatan Indikator Kinerja dan Manajemen di Bidang Lingkungan}

Lingkungan merupakan wahana atau tempat tinggal bagi seluruh mahluk hidup di dunia ini. Lingkungan adalah satu-satunya tempat bagi seluruh mahluk hidup untuk menggantungkan hidupnya. Hal ini disebabkan karena lingkungan alam mengandung harta (asset) yang melimpah, dan diperuntukan bagi kelangsungan hidup seluruh mahluk Allah swt. Harta menurut al-Qur'an dijelaskan dalam Surat Yunus ayat 55 dan Surat Al-Baqarah ayat 29, yaitu:

Terjemahnya:

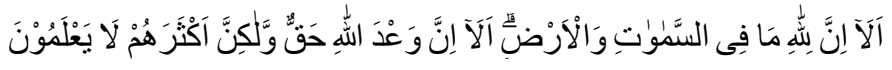

Ingatlah, Sesungguhnya kepunyaan Allah apa yang ada di langit dan di bumi. Ingatlah, Sesungguhnya janji Allah itu benar, tetapi kebanyakan mereka tidak mengetahui(nya) [QS. Yunus : 55].

Terjemahnya:

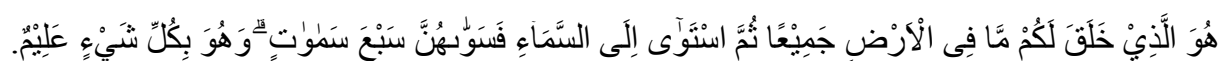

Dia-lah Allah, yang menjadikan segala yang ada di bumi untuk kamu dan dia berkehendak (menciptakan) langit, lalu dijadikan-Nya tujuh langit. dan dia Maha mengetahui segala sesuatu [QS. Al-Baqarah : 29].

Manusia diciptakan oleh Allah adalah untuk mengabdi, dan menghamba kepada-Nya secara maksimal. Harta benda yang kita miliki dapat dijadikan sarana untuk beribadah kepada Allah. Misalkan, untuk membeli makanan dan minuman, membayar zakat, infak, sedekah, menunaikan ibadah haji, membeli rumah dan kendaraan. Artinya, semua yang kita usahakan di dunia ini, dan wujud dalam bentuk materi adalah semuanya milik Allah, dan kita sebagai manusia hanya sebatas memakai semua fasilitas hidup tersebut, dalam rangka pengabdian kepada Allah Subhana WaTa'ala. sebagaimana firman Allah dalam QS. Adz-Dzaariyyaat:56.

Terjemahnya:

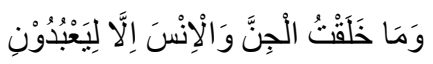

Dan Aku tidak menciptakan jin dan manusia melainkan supaya mereka mengabdi kepada-Ku [QS. Adz-Dzaariyyaat : 56]. 
Zallum (2006: 75) menyebutkan tiga jenis pengelompokan harta dalam Islam, yaitu: Pertama, sumber daya alam dan barang tambang yang tidak terbatas jumlah. Kedua, kaum Muslim dalam kehidupan sehari-harinya, memerlukan sarana dan prasarana umum yang wajib disediakan oleh negara. Ketiga, yaitu harta-harta yang keadaan asalnya terlarang bagi individu tertentu untuk memilikinya. Pengelolaan dan pemanfaatan harta harus tetap terjaga eksistensinya dari waktu ke waktu

Pengelolaan sumber daya alam berupa barang tambang kepada pihak swasta, harus didasarkan pada standar kelayakan peralatan industry yang digunakan, serta didukung oleh para tenaga ahli yang bereputasi internasional. Jika hal ini diabaikan, tidak menutup kemungkinan eksplorasi sumber daya alam di bindang pertambangan, akan memberikan dampak pada kerusakan lingkungan alam. Tragedi semburan lumpur panas yang dilakukan oleh PT Lapindo Brantas di Kabupaten Sidoarjo Jawa Timur pada tanggal 27 April 2006, adalah bukti empiris yang ditimbulkan akibat kesalahan manusia (human error), dalam upaya untuk memperoleh harta berupa barang tambang gas bumi, namun di sisi lain menimbulkan kesengsaraan yang berkepanjangan bagi masyarakat yang berdomisili di sekitar PT Lapindo Brantas.

Muchlis (2018) menyebutkan bahwa, esensi nilai-nilai maqashid syariah pada konsep menjaga dan memelihara harta dalam pendekatan indikator kinerja dan manajemen, di bidang lingkungan, yaitu lingkungan hidup merupakan harta yang tak ternilai harganya. Lingkungan hidup merupakan harta yang diwariskan oleh Allah Subhana Wata'ala kepada seluruh umat manusia dan makhluk hidup di alam raya ini. Insan (manusia) sebagai makhluk yang tertinggi derajatnya di dunia ini, harus mampu menjaga dan memelihara seluruh harta yang diwariskan Allah Subhana WaTa'ala kepadanya dengan jalan menjaga dan melestarikan lingkungan hidup secara berkelanjutan (sustainability).

\subsection{Menjaga dan Memelihara Lingkungan dalam Pendekatan Indikator Kinerja dan Manajemen di Bidang Lingkungan}

Temperatur cuaca tidak normal yang ditandai dengan musim hujan dan kemarau yang tidak beraturan, terkadang disertai dengan bencana alam yang terjadi disetiap wilayah, memberikan dampak pada tercemarnya air bersih dan lain sebagainya. Semua fenomena alam tersebut disebabkan karena kerusakan lingkungan hidup, yang biasanya ditandai dengan terjadinya pemanasan global (Yenti et al. 2020). Menyadari bahwa planet di sekitar mereka (karyawan), memiliki andil bagi keberlangsungan hidup entitas, maka lahirlah seperangkat aturan berbentuk Undang-undang, dan beraneka ragam kegiatan yang dilakukan oleh komunitas orang yang peduli akan kelestarian lingkungannya. Ending akhirnya yaitu, menghasilkan beberapa entitas mulai menyadari betapa pentingnya pengelolaan lingkungan hidup secara berkelanjutan (sustainability) (Lestari et al. 2020).

Esensi nilai-nilai maqashid syariah pada konsep menjaga dan memelihara lingkungan, dalam pendekatan indikator kinerja dan manajemen di bidang lingkungan, adalah berdasarkan Firman Allah Subhana WaTa'ala dalam al-Qur'an surat Al-A'raf ayat 56.

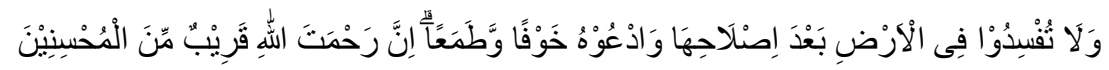

Terjemahnya:

Dan janganlah kamu membuat kerusakan di muka bumi, sesudah (Allah) memperbaikinya dan berdoalah kepada-Nya dengan rasa takut (Tidak akan diterima) dan harapan (akan dikabulkan). Sesungguhnya rahmat Allah amat dekat kepada orang-orang yang berbuat baik. 
Ayat tersebut di atas, menganjurkan seluruh umat manusia untuk berbuat baik, dan melarang untuk merusak lingkungan alam. Menyerukan kepada seluruh umat manusia untuk menjaga, dan memelihara kelestarian lingkungan alam. Mari kita mewariskan mata air kepada anak cucu kita, dan jangan kita mewariskan air mata kepada mereka. Salah satu konsep pelestarian lingkungan dalam Islam adalah perhatian akan penghijauan dengan cara menanam dan bertani. Nabi Muhammad shalallahu alaihi wasallam menggolongkan orang-orang yang menanam pohon sebagai shadaqah. Hal ini diungkapkan secara tegas dalam haditsnya, yang terjemahnya adalah:

"Rasulullah Shallahu Alaihi Wassalam bersabda, tiadalah seorang dari kalangan orang Islam yang menanam tanaman, atau menanam (menabur) benih tanaman, kemudian burung ataupun binatang ternak memakan (buah) tanaman itu, kecuali baginya memperoleh pahala sedekah" (HR. Bukhari, Muslim dan Turmidzi, dari Anas).

Menjaga dan memelihara kelestarian lingkungan hidup secara berkelanjutan, adalah kewajiban seluruh umat manusia yang sangat ditekankan dalam ajaran Agama Islam. Kebutuhan masa kini yang terus dikembangkan untuk kebutuhan di masa yang akan datang, adalah merupakan program-program lingkungan di Indonesia yang dirancang secara berkelanjutan (Ikhsan. 2009; 7). Adanya lingkungan yang terpelihara dan hubungan yang terjaga dengan baik terhadap masyarakat dan karyawan mengakibatkan perusahaan dapat beroperasi dengan tidak terkendala demonstrasi (Sari et al. 2020).

Eristiani dan Solovida (2019) menyebutkan bahwa, dampak kegiatan perusahaan terhadap lingkungan di sekitarnya, atau program perusahaan terkait lingkungan, adalah merupakan informasi lingkungan yang komprehenship. Hal ini bertujuan untuk melindungi kelestarian fauna dan flora dari kepunahan. Untuk mewujudkan niat dan keinginan tersebut, perlu dilakukan terobosan dan tindakan prefentif untuk melindungi dan menyelamatkan fauna dan flora, yaitu: Pertama, mengupayakan cagar alam untuk konservasi fauna-flora dan sumber daya air, untuk ketersediaan pakan peternakan kuda bagi kaum muslimin.

Kedua, himbauan penghijauan atau peremajaan di lahan-lahan gundul, siapa saja yang menanam pohon, maka akan diberi pahala, yang nilainya sama dengan sadaqah. Ditemukan banyak hadits Nabi Muhammad Shalallahu Alaihi Wasallam yang menunjukkan betapa pentingnya memelihara dan menanam berbagai macam tanaman yang bermanfaat, baik manfaat itu langsung untuk manusia, maupun untuk makhluk lainnya seperti binatang dan hewan. Rasulullah Muhammad Shalallahu Alaihi Wassalam bersabda yang terjemahnya adalah:

"Tiadalah seseorang dari kalangan orang Islam yang menanam tanaman, kecuali ia
mendapat pahala sedekah atas hasil tanaman, yang telah dimakannya. Apa yang
telah dicuri oleh orang dari tanaman itu, maka dia (si penanam) mendapat pahala
sedekah. Apa yang dimakan oleh binatang buas tanaman itu, maka dia (si penanam)
juga mendapat pahala sedekah, dan apa yang dimakan burung dari tanaman itu,
maka dia (si penanam) mendapat pahala sedekah. Dan tidaklah seseorang dapat
mengambilnya, terkecuali bahwa si penanam tetap mendapatpahala sedekah" (H.R.
Muslim dari Jabir).

Ketiga, kewajiban menanam itu bukan hanya anjuran, tetapi tuntutan yang memfaedahkan hukum wajib. Nabi Shalallaahu Alaihi Wassalam bersabda yang terjemahnya adalah: 
"Rasulullah Shalallahu Alaihi Wassalam bersabda, sekiranya kiamat datang, sedang ditanganmu ada anak pohon kurma, maka jika dapat (terjadi) untuk tidak berlangsung kiamat itu sehingga selesai menanam taanman, maka hendaklah dikerjakan" (H.R. Ahmad dari Anas bin Malik).

Sehubungan dengan penjelasan tersebut, kehidupan ini akan berjalan normal dan harmonis, jika keseimbangan terhadap kelestarian lingkungan alam dapat dijaga, dipelihara, dan dipertahankan. Artinya bahwa, Islam sangat menekankan kewajiban memelihara dan melindungi fauna (hewan). Al-Syaukani (1983) berpendapat bahwa, salah satu tanggungjawab penguasa muslim adalah memelihara sumber air dan padang rumput tempat memberi makan ternak kaum muslimin. Pendapat ini didasarkan pada hadits Nabi Shalallahu Alaihi Wasallam yang terjemahnya: "Dari Ibnu Umar, bahwa Nabi Shalallahu Alaihi Wassalam melindungi naqie, menjadikan naqie sebagai cagar alam untuk kuda. Hammad bertanya, apakah hanya untuk kudanya, dijawab bukan, melainkan untuk kuda kaum muslimin (H.R. Ahmad). Selanjutnya memberikan jaminan makanan terhadap hewan yang digunakan sebagai tunggangan atau yang diperah susunya.

Disadari atau tidak, jika kelestarian, keseimbangan, dan keselamatan lingkungan hidup (flora dan fauna) tidak dijaga dan dipelihara dengan baik, maka akan memberikan dampak buruk bagi kelangsungan hidup seluruh makhluk di dunia ini, tidak terkecuali manusia. Kesulitan hidup dan malapetaka yang menimpa manusia, sesungguhnya merupakan peringatan agar manusia sadar dan kembali mengintropeksi (muhasabah) cara hidup mereka, dalam hal ini agar mereka menuruti aturan-aturan agama dan peraturan Negara yang dikeluarkan oleh pemerintah. Hubungan antara konsep maqashid syariah dalam pendekatan indikator kinerja, dan manajemen di bidang lingkungan, dapat dilihat pada Tabel 1.

Tabel 1 Hubungan Konsep Maqashid syariah dalam Pendekatan Indikator Kinerja dan Manajemen di Bidang Lingkungan

\begin{tabular}{|c|c|c|c|c|c|c|}
\hline $\begin{array}{c}\text { Konsep } \\
\text { Maqashid } \\
\text { Syariah }\end{array}$ & $\begin{array}{c}\text { Memelihara } \\
\text { Agama }\end{array}$ & $\begin{array}{l}\text { Memelihara } \\
\text { Jiwa }\end{array}$ & $\begin{array}{c}\text { Memelihara } \\
\text { Akal }\end{array}$ & $\begin{array}{l}\text { Memelihara } \\
\text { Keturunan }\end{array}$ & $\begin{array}{c}\text { Memelihara } \\
\text { Harta }\end{array}$ & $\begin{array}{l}\text { Memelihara } \\
\text { Lingkungan }\end{array}$ \\
\hline $\begin{array}{l}\text { Pendekatan } \\
\text { Indikator } \\
\text { Kinerja dan } \\
\text { Manajemen di } \\
\text { Bidang } \\
\text { Lingkungan }\end{array}$ & $\begin{array}{l}\text { Kewajiban } \\
\text { penduduk di } \\
\text { suatu negeri } \\
\text { menjadikan } \\
\text { agama sebagai } \\
\text { pedoman } \\
\text { hidupnya. } \\
\text { Jika hal ini } \\
\text { ditaati, maka } \\
\text { niscaya } \\
\text { tercipta } \\
\text { lingkungan } \\
\text { alam yang } \\
\text { akan } \\
\text { memberikan } \\
\text { kebaikan dan } \\
\text { manfaat bagi } \\
\text { seluruh } \\
\text { kehidupan } \\
\text { umat } \\
\text { manusia. }\end{array}$ & $\begin{array}{l}\text { Manusia tidak } \\
\text { boleh bunuh } \\
\text { diri, dan } \\
\text { membunuh, } \\
\text { serta } \\
\text { memusnakan } \\
\text { ekosistem dari } \\
\text { habitat } \\
\text { mahluk hidup } \\
\text { di alam raya } \\
\text { ini. } \\
\text { Membunuh } \\
\text { mahluk lain, } \\
\text { tanpa alasan } \\
\text { yang di } \\
\text { benarkan oleh } \\
\text { syar'i, maka } \\
\text { sungguh ia } \\
\text { telah } \\
\text { membuat } \\
\text { kerusakan } \\
\text { lingkungan } \\
\text { alam }\end{array}$ & $\begin{array}{l}\text { Akal yang } \\
\text { sehat } \\
\text { senantiasa } \\
\text { melahirkan } \\
\text { pemikiran dan } \\
\text { ide cemerlang, } \\
\text { yang akan } \\
\text { memberikn } \\
\text { kebaikan dan } \\
\text { kemaslahatan } \\
\text { hidup di } \\
\text { manusia di } \\
\text { dunia dan di } \\
\text { akhirat kelak. } \\
\text { Akal yang } \\
\text { sehat akan } \\
\text { membawa } \\
\text { kedamaian, } \\
\text { kesejahteraan, } \\
\text { dan kan } \\
\text { keselamatan } \\
\text { bagi lingkungan } \\
\text { alam di dunia } \\
\text { ini }\end{array}$ & $\begin{array}{l}\text { Islam } \\
\text { mengharamka } \\
\mathrm{n} \text { perzinahan } \\
\text { dan } \\
\text { menghalalkan } \\
\text { pernikahan. } \\
\text { Diperlukan } \\
\text { Peningkatan } \\
\text { pemahaman } \\
\text { keagamaan } \\
\text { (keislaman) } \\
\text { bagi para } \\
\text { generasi } \\
\text { muda, dan di } \\
\text { lingkungan } \\
\text { masyarakat } \\
\text { secara umum }\end{array}$ & $\begin{array}{l}\text { Insan sebagai } \\
\text { yang tertinggi } \\
\text { derajatnya, } \\
\text { harus mampu } \\
\text { menjaga dan } \\
\text { memelihara } \\
\text { seluruh harta } \\
\text { yang } \\
\text { diwariskan } \\
\text { Allah Subhana } \\
\text { WaTa'ala } \\
\text { kepadanya } \\
\text { dengan jalan } \\
\text { menjaga dan } \\
\text { melestarikan } \\
\text { lingkungan } \\
\text { hidup secara } \\
\text { berkelanjutan }\end{array}$ & $\begin{array}{l}\text { Memelihara } \\
\text { lingkungan } \\
\text { merupakan } \\
\text { hal yang } \\
\text { sangat penting } \\
\text { dan utama, } \\
\text { karena jika } \\
\text { lingkungan } \\
\text { rusak, maka } \\
\text { kehidupan } \\
\text { manusia akan } \\
\text { terancam } \\
\text { eksistensinya. }\end{array}$ \\
\hline
\end{tabular}

Konsekuensi dari perilaku atau tindakan membuat kerusakan lingkungan, manusia wajib bertanggungjawab. Tanggungjawab di dunia berupa; pertama, kembali sadar dan tidak mengulangi lagi perbuatannya yang merusak lingkungan, kedua, memperbaiki lingkungan yang telah dirusaknya, sehingga dapat berfungsi 
kembali sesuai dengan tujuan penciptaannya, dan ketiga, membayar ganti rugi, sekiranya perbuatan itu merugikan Negara atau masyarakat. Sedangkan tanggungjawab akhirat, yaitu dalam bentuk sanksi atau ganjaran berupa dosa dan masuk neraka. Jadi, seseorang yang merusak lingkungan, wajib diberi sanksi/ganjaran, baik sanksi/ganjaran dari Negara atau pemerintah, maupun sanksi/ganjaran agama dari Allah Subhana Wata'ala (Salim. 1990).

Niat baik disertai dengan upaya untuk memasukkan konsep menjaga dan memelihara lingkungan menjadi konsep yang keenam dalam maqashid syariah, sudah sangat tepat dan sesuai dengan kondisi saat ini. Menurut peneliti, konsep menjaga dan memelihara lingkungan merupakan perintah semua agama di dunia ini. Dalam ajaran agama Islam, menjaga dan memelihara lingkungan merupakan amanah dari Allah Subhana Wata'ala, yang sudah sangat jelas tercantum dalam alQur'an, dan Hadits, serta juga dijelaskan dalam Ijtihat dan Qiyas. Dalam tataran realitas, lima konsep maqashid syariah Imam Asy Syatiby, tidak dapat dijalankan dengan baik di tengah-tengah kehidupan umat manusia, jika tidak di dukung oleh kondisi lingkungan hidup yang aman dan kondusif.

\section{SIMPULAN}

Operasionalisasi menjaga agama dalam konsep maqashid syariah pada pendekatan indikator kinerja dan manajemen, di bidang lingkungan yaitu, menekankan pada aspek Zakat, Infak, dan Sedekah (ZIS). Operasionalisasi menjaga jiwa dalam konsep maqashid syariah pada pendekatan indikator kinerja dan manajemen di bidang lingkungan, yaitu menekankan pada aspek kesehatan. Operasionalisasi menjaga akal dalam konsep maqashid syariah pada pendekatan indikator kinerja dan manajemen di bidang lingkungan, yaitu menekankan pada aspek pendidikan. Operasionalisasi menjaga keturunan dalam konsep maqashid syariah pada pendekatan indikator kinerja dan manajemen, yaitu, menekankan pada aspek kehidupan sosial kemasyarakatan. Operasionalisasi menjaga harta, dalam konsep maqashid syariah pada indikator kinerja dan manajemen di bidang lingkungan yaitu, menekankan pada aspek ekonomi. Operasionalisasi menjaga lingkungan, dalam konsep maqashid syariah pada indikator kinerja dan manajemen di bidang lingkungan yaitu, menekankan pada aspek flora dan fauna.

Konsep maqashid syariah sudah masuk kedalam ranah kaidah uzhul fikih. Artinya, konsep maqashid syariah tidak hanya terbatas pada lima konsep yang dipopulerkan oleh Imam Asy Syatiby, atau enam konsep dalam pembahasan hasil penelitian ini, namun saat ini, sudah ada tujuh konsep maqashid syariah, yaitu konsep menjaga dan memelihara umat. Enam konsep maqashid syariah yang telah dibahas, adalah merupakan keterbatasan dalam hasil penelitian ini. Diharapkan kedepan konsep maqashid syariah dalam hal menjaga dan memelihara umat, dapat dijadikan sebagai agenda masa depan yang berkelanjutan untuk diteliti.

\section{REFERENSI:}

Al-Qur'an \& Terjemahnya. Juz 1-Juz30. (2016). Kementerian Agama Republik Indonesia. Penerbit: CV Pustaka Agung Harapan. Jakarta.

Abdullah. 2010. Konservasi Lingkungan Dalam Perspektif Ushûl Al-Fiqh. Artikel. Millah Edisi Khusus Desember.

Anis, Sabijono, dan Walandouw. (2020). Penerapan Akuntansi Lingkungan Dalam Hal Pengelolaan Limbah Produksi Pada Perusahaan Pengalengan Ikan Tuna PT. Samudra Mandiri Sentosa Bitung. Going Concern : Jurnal Riset Akuntansi 15 (3): 360-365. 
Afazis dan Handayani. (2020). Penerapan Akuntansi Manajemen Lingkungan Terhadap Kinerja Keuangan: Kinerja Lingkungan sebagai Pemediasi. Jurnal Bisnis dan Akuntansi. 22 (2): 257-270.

Bahsoan. (2011). Mashlahah sebagai Maqashid Al Syariah. Tinjauan dalam Perspektif Ekonomi Islam. Jurnal Inovasi. 8(1).

Chapra. (2008). The Islamic vision of development in the light of Maqasic al-Shariah. Ocassional paper series 15. The International Institution of Islamic Thought, London-Washington.

Creswell. (2014). Research Design: Pendekatan Kualitatif, Kuantitatif dan Mixed. Yogyakarta: Pustaka Pelajar.

Eristiani dan Solovida. (2019). Dampak Informasi Sosial Dan Lingkungan Terhadap Keputusan Manajer. Jurnal Akuntansi dan Auditing 16(1): 76-101.

Ghufron. (2010). Fikih Lingkungan. Jurnal Al- Ulum. 10 (1):159-176.

Gassing. Fiqih Lingkungan. 2005. Telaah Kritis tentang Penerapan Hukum Taklifi dalam Pengelolaan Lingkungan Hidup. Makassar: FS. IAIN/UIN. . Menggapai Kemaslahatan. 2010. Harian Tribun Timur. Makassar.

Global Reporting Initiative. (2013). G4 Pedoman Pelaporan Berkelanjutan. Prinsipprinsip Pelaporan dan Pengungkapan Standar. Terjemahan Disponsori oleh: Schweizerische Eidgenossenschaft Confédération Suisse Confederazione Svizzera Confederaziun svizra. Swiss Confederation Federal Department of Economic ffairs, Education and Research EAER State Secretariat for Economic Affairs SECO.

Habsy. (2017). Seni Memehami Penelitian Kuliatatif Dalam Bimbingan Dan Konseling: Studi Literatur. JURKAM. 1(2): 90-100.

Ikhsan. (2008). Akuntansi Lingkungan dan Pengungkapannya. Penerbit: Graha Ilmu. Edisi Pertama. Cetakan Pertama.

Ikhsan. (2009). Akuntansi Manajemen Lingkungan. Penerbit Graha Ilmu. Edisi Pertama. Cetakan Pertama.

Kartini. 2013. Corporate Social Responsibility. Transformasi Konsep Sustainability Management dan Implementasi di Indonesia. Penerbit: PT Refika Aditama. Cetakan Kedua.

Kasdi. A. (2014). Maqasyid Syari'ah Perspektif Pemikiran Imam Syatibi Dalam Kitab Al-Muwafaqat. YUDISIA, Vol. 5, No. 1, Juni.

Khatib. S. (2018). Konsep Maqashid Al-Syari'Ah: Perbandingan Antara Pemikiran AlGhazali dan Al-Syathibi. Jurnal. MIZANI: Wacana Hukum, Ekonomi dan Keagamaan. Volume 5, No. 1.

Kurniawan dan Hudafi. (2021). Konsep Maqashid Syariah Imam Asy-Syatibi Dalam Kitab Al-Muwafaqat. Al-Mabsir. Vol. 15, No. 1, Maret.

Lako. 2018. Akuntansi Hijau. Isu Teori dan Aplikasi. Penerbit: Salemba Empat. Edisi Pertama.

Lestari, Yudantara, dan Kurniawan. (2020). Analisis Potensi Pelaporan Akuntansi Lingkungan sebagai Bentuk Pertanggungjawaban Perusahaan terhadap Lingkungan (Studi pada PG Madukismo Cabang Denpasar). Jurnal Ilmiah Akuntansi dan Humanika, Vol. 10 No. 1, Januari-April. ISSN: 2599-2651.

Muchlis. (2018). Membangun Konsep Operasional Maqashid Syariah dalam Membingkai Corporate Social Responsibility. Upaya Membumikan Nilai-nilai Islam dalam Entitas di Perbankan Syariah. Disertasi. PPS-FEB. Universitas Sebelas Maret. Surakarta.

Muin. (2014). Ayat-Ayat Al-Qur'an Tentang Larangan Khamr/Narkoba, Judi dan Zina. Bulukumba. 
Mulawarman A. D. dan Triyuwono. (2007). Rekonstruksi Teknologi Integralistik Akuntansi Syari'ah: Sharfate Value Added Statement. Jurnal Akuntansi dan Keuangan Indonesia. Juni Vol. 4, No. 1. Hal. 1-24.

Rizal. J.G. (2021). Ramai Soal Unggahan Gambar Penyusutan Hutan Kalimantan, Benarkah Separah itu?. Artikel: Kompas.com.

Statement of Financial Accounting Concepts. 1991. Homewood, IL: Irwin.

Salim. (1986). Pembangunan Berwawasan Lingkungan. LP3ES. UI. Jakarta.

Salim. (1990). Metoda Dakwah untuk Menanggulangi Lahan Kritis: Sebuah Telaah Qur'ani. Laporan Penelitian. P3M. IAIN Alauddin. Ujung-Pandang.

Sari, Said, dan Mediaty. (2020). Akuntansi Sosial dan Lingkungan: Implementasi Akuntansi Lingkungan Terhadap Kinerja Perusahaan. Program Pascasarjana Program Studi Akuntansi Universitas Hasanuddin Makassar.

Yenti, Candra, and Juliati. (2020). The Application of Environmental Accounting on Operational Cost of Waste Management at Prof. Dr. M.A. Hanafiah SM Hospital Batusangkar. Jurnal Imara. 4(1)

Zallum. (2006). Sistem Keuangan di Negara Khilafah. Pustaka Thariqul Izzah. Bogor.

Zulfikar, Chottam, dan Wati. (2020). Analisis Penerapan Akuntansi Lingkungan pada Program Konservasi Lingkungan PT. Pupuk Kaltim di Bontang. Jurnal Eksis. 16(2). 